\title{
A Brief History of the McGill Faculty of Medicine
}

\section{Dear MJM:}

Since this is the premiere issue of the McGill Journal of Medicine, I feel that this would be an appropriate time to provide your readers with a brief history of the rise and early development of McGill's Medical Faculty. In addition, achievements by distinguished alumni will be mentioned. I hope this historical overview of the McGill Faculty of Medicine will put your endeavors in perspective.

In the post-Napoleonic war era, Montreal was filled with poor and sick immigrants. Out of charity, a generous lady named Benaiah Gibb founded the Female Benevolent Society which later established the four-roomed House of Recovery in 1817 (1,2). This was soon replaced by the larger Montreal General Hospital, which, initially, was equipped with 24 beds. The new hospital was staffed by Drs. William Robertson, Andrew Fernando Holmes, William Caldwell, and John Stephenson. These men would later become the founders of the McGill Faculty of Medicine (2).

An acute need for formal medical training was evident as low medical standards and quackery were common. The absence of facilities required for medical education was a major obstacle before the new hospital was established. As such, Dr. Stephenson took the initiative to teach and, on October 17, 1922, delivered his first lecture at the Montreal General Hospital (2). A few months later, he was joined by Drs. Holmes, Caldwell, and Robertson (1). A statement addressing the need for a permanent seminary for medical education and the difficulties met by Canadian students was drawn up by Drs. Holmes and Stephenson on behalf of the Montreal General Hospital medical staff. It was submitted to Lord Dalhousie along with a proposal to establish and incorporate a medical institution. The response was positive and the Montreal Medical Institution was founded, its first session commencing in November of 1823 (1).

In 1826, a charter was drawn up and submitted to the Solicitor General but was rejected after 18 months on the basis that the institution had no endowment, no foundation, and no affiliated "seminary of learning" (2). In order to obtain legal status, the institution was engrafted upon the newly founded McGill College and, as a result, became its Medical Faculty. This act of incorporation benefited both parties involved, since McGill College was seeking an active teaching body at the same time. Therefore, the four inspiring gentlemen who conceived this incorporation became the founders of the McGill Faculty of Medicine with Dr. Robertson being nominated as "professor," or head of the department (2). The title was later formalized to "dean" in 1854 (1). "The Statutes, Rules, and Ordinances" of the Medical Faculty, which contained regulations regarding lecture arrangements, degree qualifications, and various conducts and duties, was submitted for Royal Sanction to the Governor General on November 9, 1831, and was approbated on May 2, 1832. Thus, the "medical professorship" of the four founders was secured and the Faculty of Medicine was granted the right to confer degrees $(1,2)$.

The Faculty's first sessions took place in 1829-1830 and its first graduate, Mr. William Logie, was conferred the "Doctor in Medicine and Surgery" (M.D.) degree on May 24, 1833. The McGill medical degree was changed to "Doctor of Medicine and Master of Surgery" (M.D., cM.) in 1862. While most Canadian schools have reverted back to bestowing an M.D. degree, McGill has chosen to keep its tradition, and the M.D., cM. degree is still granted today upon graduation (1). 
Mr. Logie, the bearer of the first McGill degree as well as of the first Canadian medical degree, applied to the Montreal Board of Examiners for a license to practice. He took the matter to court when his license was refused unless further Board examinations were taken. The judgement, in 1835, ruled in favor of Mr. Logie and the Faculty, thereby marking a significant step in the Faculty's climb toward gaining recognition for its degrees (1).

Part of a university's reputation and success is attributed to the distinguished achievements of its graduates. For many, William Osler personified the "symbol of the ideal physician who combines a superb knowledge of medicine with a humanistic approach." He graduated from the McGill Faculty of Medicine in 1872, joined the faculty's teaching body after his postgraduate studies abroad, and was appointed full chair in $1876(1,3)$. He added histology to the pre-existing curriculum, which, at that time, included only pathology and physiology (1). His book, The Principles and Practice of Medicine: Designed For the Use of Practitioners and Students of Medicine, was reprinted and translated into various languages after its first publication in 1892. After he left McGill in 1884, he remained in touch with his alma mater to which he later donated his personal library. The Osler Library of the History of Medicine was thus established and continues to serve the McGill community. Osler died in 1919, and his ashes now lie in the Osler library (3).

Like other educational institutions of that era, the Faculty refused to admit female students. It was not until after World War I that the first female medical students were officially enrolled; they graduated in 1922 (3).

Maude Elizabeth Seymour Abbott was the first female graduate of the McGill Medical Faculty. She applied to the faculty in 1889 but was refused admission. Determined to receive a medical education, she gained admittance to the Bishop's Medical College which later merged with McGill in 1905. Thus, Ms. Abbott became an alumnus of the Medical Faculty only through inheritance. Not long after her return from postgraduate studies in 1897, she was appointed Assistant Curator, and later Curator, of the McGill Medical Museum. A distinguished administrator of medical museums, she would later organize the International Association of Medical Museums, while editing its journal at the same time.

She was also appointed lecturer of pathology and she rose to become an Assistant Professor in Medical Research in 1923. Recognized for her work in congenital heart disease, she published the Atlas of Congenital Heart Disease in 1936. She retired later that year, and passed away in 1940 (3).

Dr. Wilder Graves Penfield, a pioneer in the field of epilepsy and the first director of the Montreal Neurological Institute, graduated from Johns Hopkins Medical School in 1918. In 1927, he was chosen by a McGill surgery professor to specialize in neurosurgery, and finally came to McGill and to the Royal Victoria Hospital in 1928. He created the Montreal Neurological Institute in 1934 with the support of the Rockfeller Foundation, the Province of Quebec, his colleagues, and the citizens of Montreal. The Institute pooled together the expertise of numerous neurosurgeons and neurologists for the care of patients. It also combined hospital care with the scientific study of neurology. With facilities virtually unique at that time, the Institute resolved many "unanswered questions about the brain" and set the example for other similar units which would develop elsewhere later on. Dr. Penfield retired from the Institute and from his surgical practice in 1960, and became involved in many other activities, including joining the Board of Governors of McGill University. He passed away in 1976, three weeks after he completed the final draft of his autobiography, No Man Alone: A Neurosurgeon's Life.

This letter presents but a few of the key events and luminaries that have enriched the history of the McGill Faculty of Medicine. In light of the scholarly tradition of the McGill Medical Faculty, it will be the task of present and future graduates to uphold the standards set by our predecessors. The establishment of an entirely student-run journal will be a new challenge for present and future McGill students and I am delighted to see it happen. 
Renata M.W. Leong

Faculty of Medicine

McGill University

Montreal, QC, Canada H3G 1Y6

1. Frost SB. McGill University For the Advancement of Learning Vol.1. Montreal: McGill-Queen's University Press 1980:61-65, 125-140, 282-286.

2. Abbott MS. McGill's Heroic Past 1821-1921. Montreal: McGill University, 1912:14-17.

3. Bensley EH. McGill Medical Luminaries. Montreal: Osler Library, 1990:43-44, 79-81, 143-145.

Renata M. W. Leong is presently a second-year medical student at McGill University (Montreal, Quebec). She is interested in pursuing pediatrics as a specialty. 